\title{
The role played by Greek drama as a mode of communication: with special reference to Euripides and Aristophanes
}

\section{By}

Bamunusinghe Arachchige Sepali Devdini Bamunusinghe

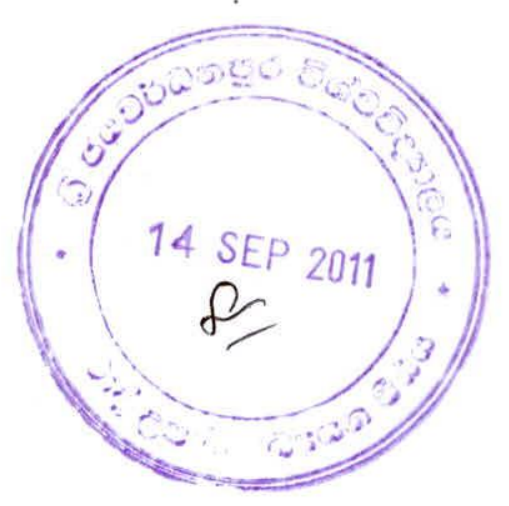




\title{
The role played by Greek drama as a mode of communication: with special reference to Euripides and Aristophanes
}

\author{
By
}

Bamunusinghe Arachchige Sepali Devdini Bamunusinghe

Thesis submitted to the University of Sri Jayewardenepura for the award of the Degree of Master of Arts in Cultural Studies $7^{\text {th }}$ December 2010 


\section{Declaration}

The work described in this thesis was carried out by me under the supervision of Professor Walter Marasinghe and a report on this has not been submitted in whole or in part to any university or any other institution for another Degree/Diploma.

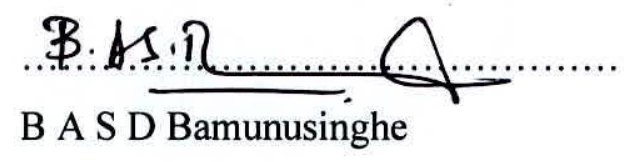




\section{Declaration by the Supervisor}

This thesis which is produced by B A S D Bamunusinghe as a requisite of the Masters of Arts Degree in Cultural Studies has been completed under the supervision of me. I hereby certify that this research thesis meets the required standard and it is recommended for the

this has been dib revised as per tugsestecins hade is tar examinen.

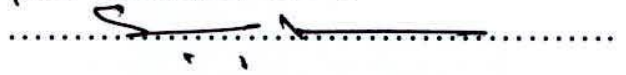

Professor Walter Marasinghe 


\section{Acknowledgements}

First of all I would like to extend my gratitude to my supervisor Professor Walter Marasinghe for the intellectual guidance rendered, being a guide throughout these two years, directing me through the right path. Though he is an expertise in this field, being so humble, he never failed to listen to my view points and always appreciated. There was never a distance between us, though I was the student and he the supervisor, as he always stayed behind me as a fatherly figure.

It's my duty to thank Dr. Saman Chandra Ranasighe, Head of the Department of Languages and Cultural Studies for accepting me as a post-graduate student of the Department and supporting me immensely whenever I needed a helping hand. Whenever stepped into the Department, I always felt like home and he always assured that I was treated right within his walls.

I also wish to thank Professor Gnanadasa Perera for encouraging me to carry on this study and for the instructions provided. Whenever I met him somewhere, his first question would be to know whether I'm progressing in the research and reminded me always to finish the thesis on time.

I am indebted to my university of Kelaniya for planting the enthusiasm for the subject of Western Classical Culture and my sincere gratitude goes to my dear lecturers at the Department. It is this very passion that drove me to pursue this subject area for my Masters. 


\section{Contents}

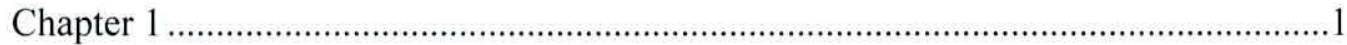

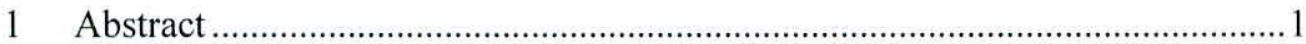

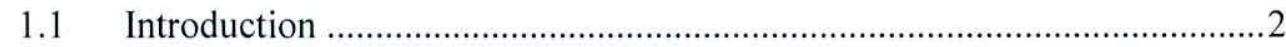

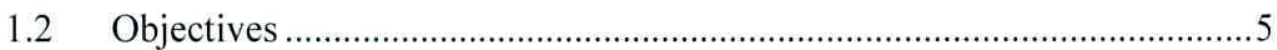

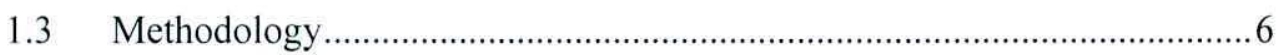

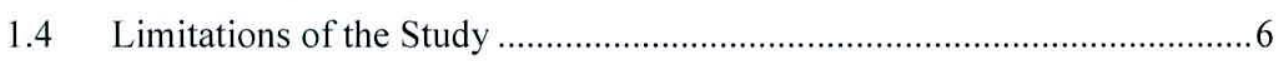

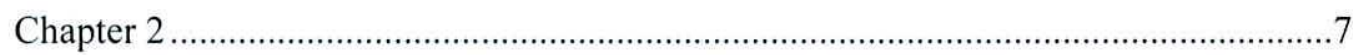

2. Greek Tragedy and Greek Comedy ..............................................................

2.1 Evolution of Greek Comedy ..................................................................... 17

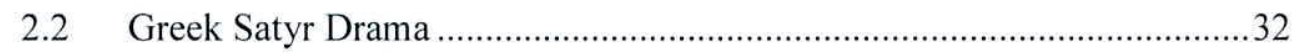

2.3 Performance Culture in Greek Life …........................................................ 34

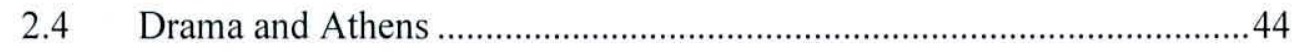

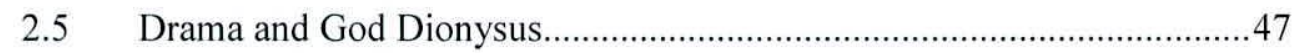

2.6 The Dramatic Festivals ………………..................................................56

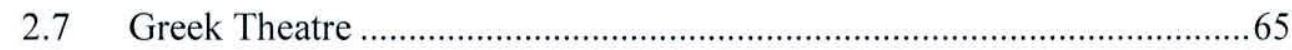

2.8 Greek Tragedians: Aeschylus, Sophocles and Minor Tragic Poets...........69

2.9 Greek Comedians: Menander and Minor Comic Poets ..............................78

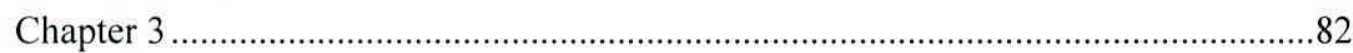

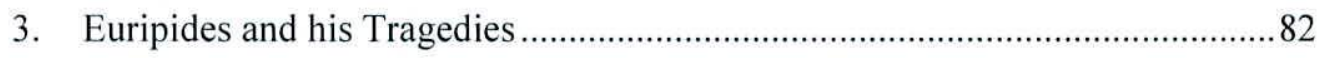

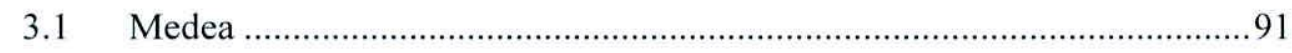

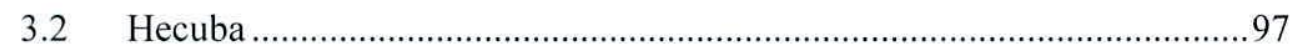

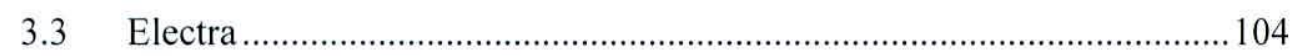

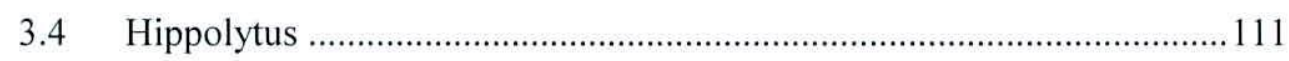

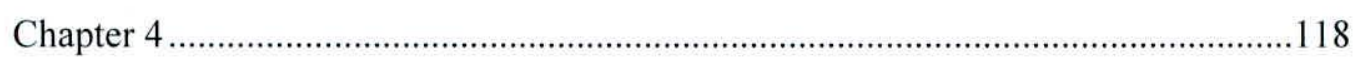

4. Aristophanes and his Comedies ............................................................... 118

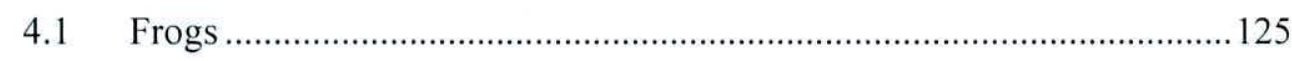

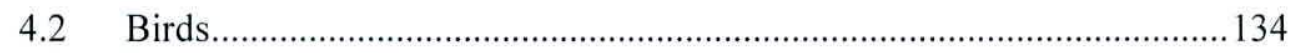

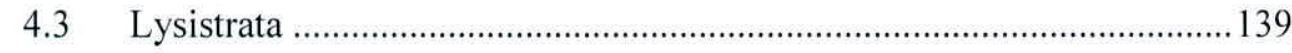

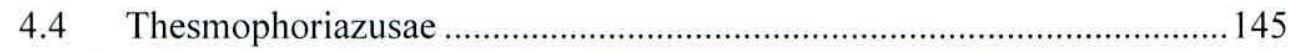

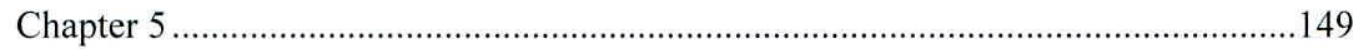

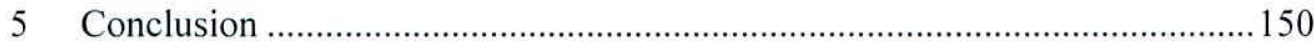

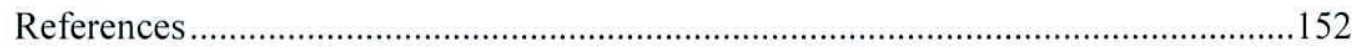




\section{Chapter 1}

\section{Abstract}

The beginning of Greek drama goes back to thousands of years. It was a gift not only to the Western world, but also to the whole world of arts. The three distinct genres of Greek drama being tragedy, satyr-play a nd comedy, the y were performed at the dramatic festivals of the Greek world, namely, the City Dionysia and Lenaia.

In the Greek world, drama was a part of their lives, something intimate, frequent and inseparable. It was not the individual preference that took the mass to the Greek theatre but as a nation, they were a part of this process of dramas, which came in the guise of rituals of festivals, held in honour of the gods they believed in. The drama festivals were held in honour of god Dionysus, the god who gifts fruitfulness and contentment to the human beings as well as the one who represents the tragic sense of humanity and nature as well, the two beautiful extremes visible in Greek tragedy and Greek comedy.

Drama and drama festivals were facilitated with state recognition and were always sponsored by the rulers of the city-states while encouraging the citizens to participate in them. Massive theatre structures were constructed, providing seating capacity for thousands. Within such appealing circumstances, Greek drama has evolved through time, gifting outstanding dramatists and drama compositions to the world of aesthetics. Greeks being a nation whose lives were embedded in a performance culture, drama was the most effective and intimate to be utilized as a mode of communication, during such an ancient period where there were no other modes of communication like in the world of today. 


\section{$1.1 \quad$ Introduction}

History of Greek drama goes back to centuries of years while most of the historians believe that it began long before $700 \mathrm{BC}$ and that the foundation of western drama was laid upon the Hellenic soil. Greek peninsula is situated in the Aegean Sea which is sprinkled with a number of small islands. The season of summer is hot in Greece but the constant winds which are blowing across the sea during sunset, soothes the temperature. Since rains as well as snowing are rare in Greece, it is clear why the Greeks preferred a life out-of-house rather than restricting themselves within the domestic limits. Thus not only their drama festivals, athletic competitions and religious festivals but their political meetings and philosophical discussions were also held outdoors. Even during such an ancient era, it is surprising how the Greeks have found the laws of ethics, ruling systems such as oligarchies, monarchies and democracies and also the mastery in sculpture, architecture and pottery while laying the foundation for modern science and philosophic theories. Therefore it is clear that it was within such a developed civilization that we meet these Greek dramatists and their compositions, themes they have touched upon, the contemporary subject matters they have discussed and the dark human emotions they have brought out in to light.

Throughout history, it is visible that Greek dramas have played a crucial role in the Greek world, affecting its culture, social elements, religious rights and day today life. There has been a performance culture in Athens, connected with politics, law, religion, athletics, festivals, music and poetry. In every aspect of Greek culture, there were the notions of a performing nature, thus 'drama' was a very intimate mode for the Greeks and this could be one reason for the drama to be so associated with Greek life.

As history unveils, not only in the city-states of Greece but also in the foreign Greek colonies, there have been developed dramas but unfortunately only a limited number of them remain at the moment and in amount, it is probably one tenth of the dramas which have been composed and produced by the ancient Greeks. Although the term 'Greek Drama' indicates dramas sprung up from the whole Greek world, it should be realized that the dramas that we read today are the dramas which were composed and produced in the Athenian world. Most of the literary compositions of the $5^{\text {th }}$ and $4^{\text {th }}$ 
centuries are dramas and that was the golden period of Greek drama and it is clear that although it was a time of conflict and chaos in Athens, mainly due to the Persian Wars, it has not disturbed or interrupted dramatic activities. It is still an unanswered question whether during that particular era all the other literary compositions were on hold or whether they were not powerful enough to challenge the great drama compositions that are left with us at present. An admirable support and encouragement was rendered by the Athenian government for the enhancement of Greek drama and the aesthetic activities in the city-state and out of the rulers of Athens, Peisistratus, Hipparchus, Themistocles and Pericles are outstanding in this regard. Therefore within such appealing circumstances, Greek Dramatists were able to communicate well with the public through their dramatic productions.

With regard to the birth and evolution of Greek drama, although there are numerous notions which explain its beginning, the most believed concept is that it evolved along with Greek mythology, Greek divinity and the religious rituals. The Olympic pantheon reigned by the great god Zeus and the rest of the gods and goddesses were the ultimate representation of power for the Greeks. As in most of the other ancient civilizations, Greeks also believed that their gods and goddesses rep resented the natural phenomena and powers such as sun, ocean, water, wind, thunder, rain and also human emotions such as war and power, love, jealousy and anger. The gods who favored a certain nation of a city-state brought ill-luck to the rival nations; they blessed their favorites and cursed the foes or sometimes turned a deaf ear on the prayers of the people. But the Greeks were of the strong belief that these gods protected them and guided them in all their endeavors.

Agriculture and cultivation played a major role upon the Greeks. The agrarian festivals were meant to promote fertility in crops and upgrade the quality and the quantity of the agricultural products. When examining the festivals of the Greeks, it is visible how accurately they have lined up their festivals annually at definite seasons of the year which at the same time proves their practicality. Since the Greeks being strong believers in divinity, their drama festivals were also held in honour of their favorite god Dionysus and one such was the drama festival, the 'City Dionysia'. The god Dionysus brings joy, hope and warmth during spring and summer but gifts darkness, emptiness and coldness during autumn and winter and that is exactly what 
we experience in Greek tragedy and Greek comedy which stand for the two extremes of humanity and life. Another concept on the birth of Greek tragedy is the 'Dithyramb'. It was a chorus of singers who danced and sang prayers for the god Dionysus, wearing goat skins in the guise of goats. These members of the 'Dithyramb' were called 'Tragodai' and later it may have transformed to 'Tragodia'. Gradually, the number of 'Dithyramb' chorus groups increased in number and the priests of the temple of Dionysus tend to organize competitions among these groups of singers. Therefore it could be assumed that these competitions must have an impact on the foundation of Greek drama.

The massive structures of Greek theatres provided more than enough space for every citizen and, as history unveils, the government has provided money for the poor citizens to participate in the festival. Well renowned theaters in Greece such as the theater of Epidaurus and the theatre of Dionysus were colossal theatre structures which have provided space for the audience from 20,000 to 35,000. For the Greeks, these drama festivals were not held with the intention of financial gains, but they were a kind of religious festivals carried out in order to enhance the piety and devotion of the masses.

Since Greek drama was a mode of art which had such an impact over the Greek life style and Greek culture, its popularity among the people was irresistible. While the Greek tragedians attempted to touch on the untouched deep human emotions and concepts with the appropriate use of the subject matters and tragic characters, even the comic writers were successful enough to convey the bitter truths about humanity and current issues as bitter pills coated with sugar of laughter. The public who roared with laughter within the theater, on their way home, pondered over their own laughter and that was the wonderful space created by the comedians for the mass to understand the bitter truths which were discussed upon the stage. Although the beginning of drama was the religious rituals, once it established as an accepted mode of art in Greek culture, the dramatists were not reluctant to go into philosophical aspects of humanity and world which they observed around them through their drama compositions. Human existence, nature of the world, destiny or fate which could not be altered even by the divine intervention and tragic sense of humanity which prevails within the human soul are such themes that the Greek dramatists handled. 
The dramas were regarded as a mode of education for the adult citizens of the city as well and as Aristophanes the comedian mentions in his drama Frogs, 'school boys have a master to teach them, grownups have the poets'. Aristophanes believed that the function of good poetry was to provide moral and political guidance to the lost citizens in order to create a better city. The poets and the dramatists were considered important as they were accepted as the teachers of the adult citizens. At the same time they believed that drama should be a mode of communication to the Athenian mass to arm them with patriotism towards their city against barbaric invaders.

Therefore it is clear that Greek drama has played an immense role in Greek culture as a mode of communication. During such an ancient period, there were no such modes like today to address the mentality of the common man of the society and this could be done only through drama which was the most intimate and reliable medium available for the dramatists. Thus, the dramatists both tragedians and comic writers, were very successful in addressing the burning issues of the day and revolutionizing the attitudes of the common man through their literary masterpieces, philosophic concepts and dramatic characters.

\subsection{Objectives}

In the ancient Greek Civilization, Greek dramas have played an immense role in Greek culture and even now when referring to the ancient drama scripts by the Greek tragedians and comic writers, it is visible that they inherit a universal quality with regard to their character portrayals, themes and the subjects they have touched.

Therefore one of the main objectives of carrying out this research is to discuss the effective role played by Greek drama in Greek culture as a mode of communication and at the same time to identify the reasons for Greek drama to stand out as one of the strongest modes of communication for the mass of the Greek world.

Another objective of carrying out this research is to discover the issues and themes that the dramatists have addressed through their dramas. At the same time this research is an attempt to study separately the role played by the tragedians and comic writers and the different ways they have handled social and human issues. It is true 
that both tragedies and comedies have their own structure and style but what is interesting to be noted is the manner in which they have brought irony, sarcasm, grim laughter and philosophy of life through their drama compositions. To identify the manner in which drama influenced and modeled the attitudes and mentality of the Greeks is another objective of carrying out this research.

\subsection{Methodology}

When carrying out this research; standard written texts, refereed journals and anthologies of scholarly articles were utilized. The attempt which was taken to refer the latest publications and current web articles provided the opportunity to carry out the study in a much updated manner. The readings were done along with the drama scripts and different interpretations brought out by different critics. The brain storming sessions were carried out with the supervisor which brought an immense impact over the way of thinking on the topic of the study.

\subsection{Limitations of the Study}

This study is confined to the five main dramatists of the Greek world namely, Aeschylus, Sophocles, Euripides, Aristophanes and Menander, whose works are available in print. Out of the tragedians, a special preference is paid to Euripides with special analysis on his selected dramas namely Medea, Hecabe, Electra and Hippolytus. Out of the comic writers of the Greek world, Aristophanes and his selected dramas are given special reference, namely Frogs, Birds, Lysistrata and Thesmophoriazusae. 


\section{Chapter 2}

\section{Greek Tragedy and Greek Comedy}

Greek drama was a gift not only to the Western world, but also to the whole world of humanity and the history of Western drama begins in the mid-sixth century at Athens. ${ }^{1}$ The high period of Greek drama was the era from the sixth to the mid-third century and the fifth century was the pinnacle of Greek drama, when most of the plays that we possess were produced. There are three distinct genres of Greek drama, namely, tragedy, satyr-drama and comedy and they were performed at the same festivals, but each had its own distinguishing features. When a new papyrus fragment of an unknown dramatic text is discovered, it is nearly always possible to assign it to its correct genre on the basis of language, metre and content. ${ }^{2}$ By the middle of the fourth century BC, Athens and possibly all of Greece must have been awashed with drama scripts. ${ }^{3}$ As history unveils, at Athens' Great City Dionysia, at least fifteen new scripts were presented every year and assuming that these contests were held annually for hundred years, 900 tragedies, 300 satyr plays and more than 300 comedies would have been presented, which make a total of 1500 original drama scripts written in the course of hundred years for City Dionysia. There were also at least four other festivals in Athens, namely the Anthesteria, Lenaia, Rural Dionysainad and Panathenaia, where the dramas were presented and also in the other city-states there may have been playwrights creating more drama scripts. In the Greek world, drama was a part of their lives, something intimate and frequent. It was not their individual preference that took them to the Greek theatre but as a nation, they were a part of this process of dramas, which came in the guise of rituals and festivals, held on behalf of the supernatural powers they believed in.

In earlier dramatic cultures, however, the space comes first and imposes its own rules on the performance. The art of the theatre did not spring fully born into the world. In all the manifestations that we know, drama emerged as a by-product of some other

\footnotetext{
${ }^{1}$ Storey, Ian, C. and Allan, Arlene, A Guide to Ancient Greek Drama, Blackwell publishing Ltd, UK, 2005, p.01.

${ }^{2}$ Sommerstein, Allan, H, Greek Drama and Dramatists, Taylor and Francis e-Library, 2004, p.01.

${ }^{3}$ Ashby, Clifford, Classical Greek Theatre: new views of an old subject, Lowa City: University of Lowa Press, 1999, p.02.
} 
activity, usually some magico-religious activity.' The first actors were priests, shamans or sacred dancers and the emergent dramas were first performed in spaces that had been designed for other purposes. The same situation could be identified at the roots of Greek drama, since we are aware of the fact that the beginning of Greek drama is connected with Greek religion and Greek religious festivals.

Drama is action ${ }^{2}$ a nd according to Aristotle', the dramatists 'represent people in action' which was a different notion to the third-person narrative in Homer's epics. For both Plato and Aristotle, the two great philosophers of the fourth century, drama is an example of mimesis, "imitation" or "representation," but each took a different view of the matter. ${ }^{4}$ According to Plato mimesis was something to be discredited and inferior and as he believed, the ideal ruler of the ideal state should avoid mimesis. It was putting oneself into the character of another or taking on another's role, which was according to Plato, morally inferior. But as Aristotle perceived, mimesis is not only something natural in human nature but something that generates pleasure and something essential for human learning. As Aristotle explains, "to engage in mimesis is innate in human beings from childhood and humans differ from other living creatures in that humans are very mimetic and develop their first learning through mimesis and because all humans enjoy mimetic activities". "Therefore drama is "doing" or "performance" and in human cultures, performance was a notion that was embedded specially in the religious and ritual context such as the elaborate dances of the Shakers; the complex rituals of the Navaho peoples; the mediaeval mystery plays, which for a largely illiterate society would provide a venue for religious instruction and ritual reenactment, as well as for entertainment. ${ }^{6}$ Ian C. Storey and Arlene Allan ${ }^{7}$ denote that drama encompass science, as the dances of the Navaho provide a history of the world and a series of intricate healing ritual and according to them drama and performance often keep historical moments alive, such as legends which are based on some real historical events, but elaborated out of recognition. Greek tragedy falls partly into this category, since its themes and subjects are for the most part drawn

\footnotetext{
${ }^{1}$ Arnott, Peter, D, Public and Performance in the Greek Theatre, Taylor and Francis e-Library, 2003, p.02.

${ }^{2}$ Storey, Ian, C. and Allan, Arlene, A Guide to Ancient Greek Drama, 2005, p.01.

${ }^{3}$ Aristotle, Poetics, 1448a28

${ }^{4}$ Storey, Ian, C. and Allan, Arlene, A Guide to Ancient Greek Drama, 2005, p.01.

${ }^{5}$ Aristotle, Poetics, 1448b5-9

${ }^{6}$ Storey, Ian, C. and Allan, Arlene, A Guide to Ancient Greek Drama, 2005, p.02.

${ }^{7}$ Ibid.
} 
from the heroic age, an idealized time about a thousand years before the classical age. ${ }^{1}$ According to Ian C. Storey and Arlene Allan ${ }^{2}$ the Ramlila play cycles of northern India were a similar mixture of myth and history and provided for the Hindus the same sort of cultural heritage that Greek myths did in classical Greece. They bring an extreme example of the history-drama in the history-plays of Shakespeare, in particular his Richard III, which is based on the Tudor propaganda campaign aimed at dishonoring the last of the Plantagenets. Drama can be used to provide moral instruction. The Mystery Plays in part restated the message of the Christian gospel, while the Ramlila plays celebrate the conquest of love and devotion over malevolence and lust.

It is inevitable to agree with the fact that humans enjoy both acting in and watching performances. Aristotle is of the view that mimesis is a notion which is inborn in humanity and a source of pleasure. A theatrical experience brings pleasure, a change to the same old routine and rhythm of day today life, satisfaction by observing a story which unfolds on stage with different characters and finally an emotional experience of human nature. Even Allan H. Sommerstein indicates that role playing activities which were of a ritual or semi-ritual nature were part of Greek life. According to his view, these have been part of the life of almost all the people from the earliest times; choral dancing was a notion which was familiar in the Homer's world of epics and even archaic art represents groups of costumed dancers in fabulous costumes. But we do not know whether these were the enactments of what can truly be called drama.

Available evidence proves that the crucial time of the evolution of Greek drama was the sixth century B.C, and the crucial area was a strip of territory extending roughly east and west from Attica, through Megara and the Isthmus, to Sicyon and Phlius in the north-eastern Peloponnese. According to Herodotus the historian, the 'tragic choruses' had once sung of the misfortunes of Adrastus at Sicyon, until the tyrant Cleisthenes (600-570 BC) transferred them to the cult of Dionysus; Phlius, further inland, was the birthplace of Pratinas, the first great satyr-dramatist (who, to judge by changes in the iconography of satyric scenes in Attic art, may have moved to Athens around $520 \mathrm{BC}$ ); Megara claimed to have originated both Athenian comedy (through

\footnotetext{
${ }^{1}$ Storey, Ian, C. and Allan, Arlene, A Guide to Ancient Greek Drama, 2005, p.02.

${ }^{2}$ Ibid.
} 